\title{
SCIDiC
}

\author{
International Journal of Dentistry and Oral Science (IJDOS) \\ ISSN: 2377-8075
}

\section{Prevalence Of Benign Migratory Glossitis In Patients Visiting A Private Dental College In Chennai}

Research Article

Ilankizhai $\mathrm{RJ}^{1}$, Manjari Chaudhary ${ }^{2}$, Madhu laxmi $\mathrm{M}^{3}$

${ }^{1}$ Saveetha Dental College and Hospitals, Saveetha Institute of Medical and Technical Sciences(SIMATS), Saveetha University, Chennai 600077, Tamil Nadu, India.

${ }^{2}$ Senior Lecturer, Department of Oral Medicine and Radiology, Saveetha Dental College and Hospitals, Saveetha Institute of Medical and Technical Sciences(SIMATS), Saveetha University, Chennai 600077, Tamil Nadu, India.

${ }^{3}$ Professor, Department of Oral and Maxillofacial Surgery, Saveetha Dental College and Hospitals, Saveetha Institute of Medical and Technical Sciences(SIMATS), Saveetha University, Chennai 600077, Tamil Nadu, India.

Abstract

Benign migratory glossitis also known as geographic tongue is a recurrent condition of unknown etiology characterised by loss of epithelium particularly of the filiform papillae on the dorsum of the tongue. The aim of the study is to evaluate the prevalence of benign migratory glossitis in patients visiting a private dental college in Chennai. A retrospective study was done using the case records of patients visiting University hospital from June 2019 - December 2019. Case sheets containing information on Benign Migratory Glossitis were retrieved and analysed. In total, 38 cases were confirmed. Prevalence was found to be $0.09 \%$ and was found to be more common in males than in females. In males, geographic tongue is prevalent among the age group 19-28 yrs whereas in females it is prevalent in the age group 29-38 yrs. However, there was no statistically significant correlation between age, gender, and the presence of disease. Within the limits of the study, it can be concluded that benign migratory glossitis has a prevalence rate of $0.09 \%$ and is more common in males at a much younger age than females.

Keywords: Benign Migratory Glossitis; Geographic Tongue; Prevalence Studies; Tongue.

\section{Introduction}

Tongue is one of the most important part of the oral cavity. It is quite impossible to imagine an oral cavity without the tongue. It is responsible for numerous functions like Speech, Chewing, tasting, swallowing and in fact breathing. Thus, any lesions occurring on the tongue needs to be treated with importance and investigated thoroughly as mouth is the mirror of the body [4, 10, 52, 49]. Diagnosis of a wide variety of developmental anomalies of the tongue is an essential part of a daily dental practice $[22,25,48$, 53]. One such lesion, most commonly occurring on the tongue is Benign migratory glossitis. Benign migratory glossitis can be defined as benign Inflammatory disorder occurring on the dorsum of the tongue and can probably extend into the lateral borders. [13]. As it is asymptomatic, not much focus is thrown on this lesion when other lesions of the tongue are taken very seriously.
This study is an effort to learn more about the demographics and the Clinical features of the disorder and management Strategies. $[32,50]$.

Benign migratory glossitis is a recurrent condition of unknown etiology characterized by loss of epithelium, particularly the filiform papillae on the dorsum of the tongue[16, 21]. The loss of filiform papillae leads to mouth ulcer - like changes in the tongue which can vary in colour and size. The lesion commonly occur on the lip, lateral borders, dorsum of the tongue and sometimes even extend to the ventral portion of the tongue[2]. The location and the pattern however can change over the time, thus accounting for the name 'migratory'. The apparent migration is due to the concurrent epithelial desquamation at one location and proliferation at another site[13]. However the etiology of geographic tongue is not clear. It is found to be associated with allergies and

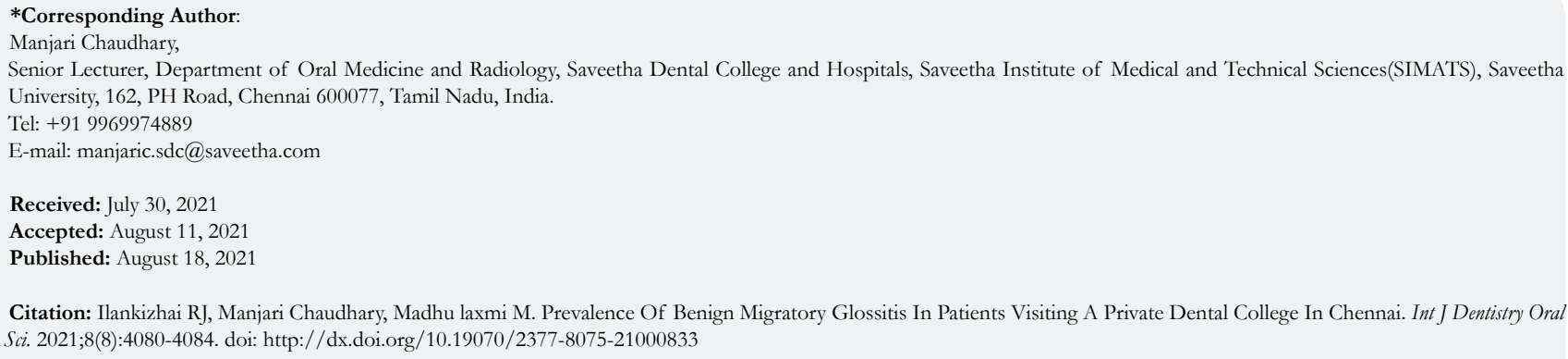

Copyright: Manjari Chaudhary ${ }^{\circ} 2021$. This is an open-access article distributed under the terms of the Creative Commons Attribution License, which permits unrestricted use, distribution and reproduction in any medium, provided the original author and source are credited. 
Psoriasis and also associated to occur along with fissured tongue.

\section{Clinical Features}

A classical geographic tongue lesion is characterised by multifocal, circinate, irregular erythematous patches bounded by slightly elevated white keratotic bands [21]. The white margin is usually 1-2 $\mathrm{mm}$ wide and is composed of regenerating filiform papillae mixed with keratin and neutrophils [13]. The erythematous patch represents the loss of filiform papillae and the subsequent thinning of epithelium in that region. The size of each of these lesions can vary from few millimeters to centimeters [13].

\section{Clinical Presentation}

This disorder was first reported by Rayer in 1831 [34]. This disorder is also known by different names such as Erythema migrans [9] , geographic Stomatitis [17], stomatitis areata migrans [45] and migratory stomatitis [56]. The majority of the patients are asymptomatic, but some Patients complain of pain and burning sensation and decreased taste Sensation [21]. This Sensation affects the functioning of the tongue, in some cases. In a few cases, even these lesions are accompanied by oral discomfort, burning Sensation, however in the majority of the patients it is asymptomatic, which is the reason why it goes unnoticed most of the time.

\section{Demographics}

The global prevalence Rate is between $1.0 \%$ and $2.5 \%$ [20]. In India, its prevalence is $0.89 \%$ and overall Prevalence is $1 \%-2.5 \%$ in the general population. [40] Females were more commonly affected [18]. Previous studies report that incidence of geographic tongue is more in the 20-29 years age group [23].

\section{Treatment}

Patients do not usually require treatment apart from reassurance [21]. Patient needs to be made aware of their diet which includes hot spicy, acidic foods [51]. which can exacerbate the symptoms Patient needs to be advised to prevent including these in their diet but also it is important to make sure the patients follow good oral hygiene practices [28]band maintain good oral health [5]. Patients needs to be made aware of existence of such conditions.

Geographic tongue seems to be a friendly condition that never changes into danger. There are no previous studies that report the complications that have originated from geographic tongue. However, it is important to know the existence and clinical features of the disease among dental professionals [27, 42] in order to educate and reassure the patients with fear regarding these lesions $[8,26]$. Previously our team has a rich experience in working on various research projects across multiple disciplines[12, 30, 38, $15,55,31,29,44,28,14,7,36,46,35,3]$. Now the growing trend in this area motivated us to pursue this project.

Thus the aim of the study was to evaluate the prevalence of benign migratory glossitis in patients visiting Saveetha dental college.

\section{Materials and Methods}

The study was carried out in an institutional setting with the advantage being a large data availability and the disadvantage being assessment of patients belonging to a similar geographic location. A retrospective study was done using the case records of patients visiting University hospital from June 2019 - February 2020. Prior permission to use the data for the study was obtained from the Institutional Review Board of the University (SDC/SIHEC/2020/ DIASDATA/0619-0320).

A total of 38 case sheets containing information on benign migratory syndrome were retrieved and the demographics of the data analysed. The collected data was subjected to photographic cross verification. The data collected was statistically analysed using SPSS Version 20.0. Descriptive statistics and chi square tests were performed. A p value of less than $0.05 \%$ was considered to be statistically significant.

\section{Results \& Discussion}

Out of the total 40,000 patients who visited a private dental college from June 2019- December 2020, 38 Patients were found to have geographic tongue, the prevalence was found to be $0.09 \%$. The results also indicated that males $(73.7 \%)$ were more commonly affected than females $(26.3 \%)$ as shown in table 1 . The mean age of the affected population was found to be $36.5 \mathrm{yrs}$ as shown in table 2 .

In females, geographic tongue is prevalent in the age group 29-

Table 1. Represents the frequency distribution of males and females. Out of the 38 patients who had Benign Migratory Glossitis, $26.3 \%$ were females and $73.7 \%$ were males.

\begin{tabular}{|c|c|c|c|c|}
\hline & Frequency & Percent & $\begin{array}{c}\text { Valid per- } \\
\text { cent }\end{array}$ & $\begin{array}{c}\text { Cumulative } \\
\text { percent }\end{array}$ \\
\hline Females & 10 & 26.3 & 26.3 & 26.3 \\
\hline Males & 28 & 73.7 & 73.7 & 73.7 \\
\hline & 38 & 100 & 100 & 100 \\
\hline
\end{tabular}

Table 2. Represents the mean age of patients with minimum and maximum age. The mean age of the participants was found to be 36.5 years with the maximum age being 67 years and the minimum age being 21 years.

\begin{tabular}{|c|c|c|c|c|}
\hline N (valid) & Mean (age) & $\begin{array}{c}\text { Standard } \\
\text { deviation }\end{array}$ & $\begin{array}{c}\text { Minimum } \\
\text { (age) }\end{array}$ & $\begin{array}{c}\text { Maximum } \\
\text { (age) }\end{array}$ \\
\hline 38 & 36.5 & 11.3 & 21 & 67 \\
\hline
\end{tabular}


Graph 1: The proportional bar chart represents the different age groups among females. The $X$ axis represents the different age groups and the $\mathrm{Y}$ axis represents the number of participants in each category. Majority of females (orange) with Benign Migratory Glossitis fall in the age group of $29-38$ years $(50 \%)$.

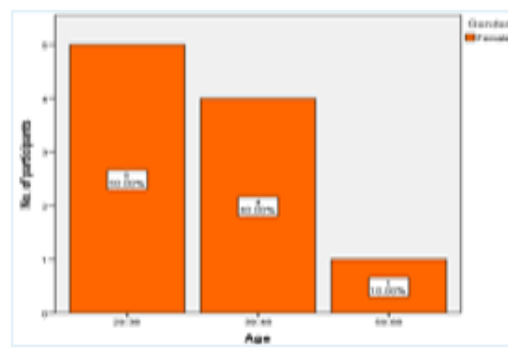

Graph 2: The proportional bar chart represents the different age groups among males. The $\mathbf{X}$ axis represents the different age groups and the $\mathrm{Y}$ axis represents the number of participants in each category. Majority of males with Benign Migratory Glossitis fall in the age group of $19-28$ yrs. $(39.2 \%)$.

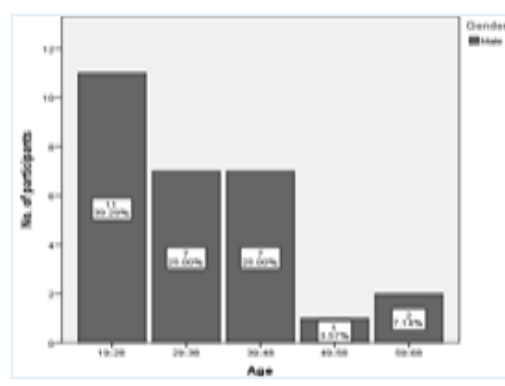

Graph 3: The proportional bar chart represents the distribution of different age groups among males and females having benign migratory glossitis. The $\mathrm{X}$ axis represents the gender and the $\mathrm{Y}$ axis represents the number of participants in each category;19-28(blue);2938(green);39-48(beige)49-58(grape vine)and 59-68(yellow). Pearson's chi square association was done. [Pearson's chi square value-6.3; $\mathrm{p}$ value:0.17(>0.05)]. Though benign Migratory Glossitis is more likely to occur in males (19-28 years) and in females (29-38 years) no statistically significant association was seen between age, gender and the occurrence of the lesion.

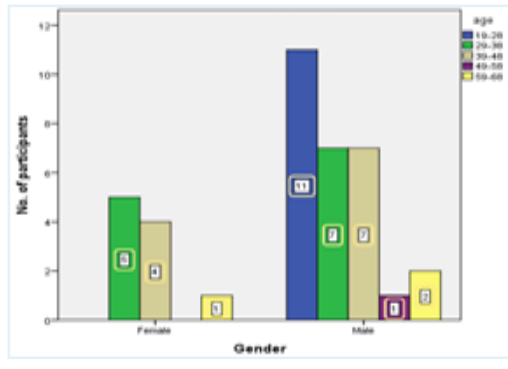

$38(50 \%)$ years as shown in graph 1 , whereas in males it is more prevalent in the age group 19-28 years (39.2\%) as shown in graph 2. Graph 3 represents the distribution of different age groups among males and females who have benign migratory glossitis. It can be reported that the disease more commonly occurs in males in 19-28 years, however there was no statistically significant ( $p>0.05$ ) association between presence of benign migratory glossitis and age or gender as determined by Pearson's chi square test. Benign migratory also known as geographic tongue is a benign asymptomatic condition of unknown etiology which is usually being missed during diagnosis or misdiagnosed as some other more serious lesion. Thus, the knowledge about this disease will prevent such happenings. There are however quite a few studies which report the demographics of this disease, but only very few studies about the demographics of this disease have been made in India.

Assimakopoulos D et al., [2] in 2002, seaport global prevalence of $0.28-14.4 \%$ which is quite high when compared to the results of our study. Similarly, Mathew AL [23] reported a prevalence of $0.84 \%$ prevalence in south Indian population. Even though, this study has similar geographic region where the study has been conducted, the prevalence reported seems to be higher than that in our study. This may be due to numerous reasons such as the subjective error during clinical examination as most of the data collected were done by intern trainees in the college.

Ishibashi et al., [18] reported that females were more commonly affected whereas which is in contradiction to our study where males were more commonly affected. Dhakal A et al., [1] reported that it occurred more in males and the prevalence was highest in the age go up 21-40 yrs which was similar to the results of our study.

Jainkittirong et al., [19] reported that incidence of geographic tongue is more in the 20-29 yrs age group which is also similar to the results of our study.

This study also had its fair share of limitations. No information regarding other lesions associated with this were collected so no association studies could be done. There was no definitive diagnostic framework on which cases could be classified. Further studies must be done with a larger sample size, association between local and systemic disorders as a next step towards understanding the disease better. Our institution is passionate about high quality evidence based research and has excelled in various 
fields $[33,35,39,11,37,46,54,6,24,41,43]$. We hope this study adds to this rich legacy.

\section{Conclusion}

Geographic tongue or benign migratory glossitis due to its asymptomatic nature has more often been ignored and not given any importance. However, clear understanding about the demographics and clinical features of the disease is of utmost importance to properly diagnose and differentiate lesions of the tongue and to provide appropriate and early treatment intervention for the respective lesions. The results show that geographic tongue has a prevalence rate of $0.09 \%$ and is more common in males at a much younger age than females.

\section{References}

[1]. Arun Dhakal Sushma Pandey. Prevalence and risk factors associated with geographic tongue in central southern part of nepal-a survey in chitwan medical college and hospitals. IJOHMR.JANUARY-FEBRUARY 2017; 3(5).

[2]. Assimakopoulos D, Patrikakos G, Fotika C, Elisaf M. Benign migratory glossitis or geographic tongue: an enigmatic oral lesion. Am. J. Med. 2002 Dec 15;113(9):751-5.

[3]. Azeem RA, Sureshbabu NM. Clinical performance of direct versus indirect composite restorations in posterior teeth: A systematic review. J. Conserv. Dent. 2018 Jan;21(1):2-9.

[4]. Chaitanya NC, Muthukrishnan A, Babu DBG, Kumari CS, Lakshmi MA, Palat G, et al. Role of Vitamin E and Vitamin A in Oral Mucositis Induced by Cancer Chemo/Radiotherapy- A Meta-analysis. J Clin Diagn Res. 2017 May;11(5):ZE06-ZE09.Pubmed PMID: 28658926.

[5]. Chaitanya NC, Muthukrishnan A, Krishnaprasad CMS, Sanjuprasanna G, Pillay P, Mounika B. An Insight and Update on the Analgesic Properties of Vitamin C. J Pharm Bioallied Sci. 2018 Jul-Sep;10(3):119-125.Pubmed PMID: 30237682

[6]. Chandrasekar R, Chandrasekhar S, Sundari KKS, Ravi P. Development and validation of a formula for objective assessment of cervical vertebral bone age. Prog Orthod. 2020 Oct 12;21(1):38.Pubmed PMID: 33043408.

[7]. Chen F, Tang Y, Sun Y, Veeraraghavan VP, Mohan SK, Cui C. 6-shogaol, a active constiuents of ginger prevents UVB radiation mediated inflammation and oxidative stress through modulating $\mathrm{NrF} 2$ signaling in human epidermal keratinocytes (HaCaT cells). J Photochem Photobiol B. 2019 Aug; 197:111518.Pubmed PMID: 31202076.

[8]. Choudhury P, Panigrahi RG, Maragathavalli, Panigrahi A, Patra PC. Vanishing roots: first case report of idiopathic multiple cervico-apical external root resorption. J Clin Diagn Res. 2015 Mar;9(3):ZD17-9.Pubmed PMID: 25954713.

[9]. Cooke BE. Erythema migrans affecting the oral mucosa. Oral Surg Oral Med Oral Pathol. 1955 Feb 1;8(2):164-7.

[10]. Dharman S, Muthukrishnan A. Oral mucous membrane pemphigoid - Two case reports with varied clinical presentation. J Indian Soc Periodontol. 2016 Nov-Dec;20(6):630-634.Pubmed PMID: 29238145.

[11]. Ezhilarasan D, Apoorva VS, Ashok Vardhan N. Syzygium cumini extract induced reactive oxygen species-mediated apoptosis in human oral squamous carcinoma cells. J Oral Pathol Med. 2019 Feb;48(2):115-121.Pubmed PMID: 30451321.

[12]. Ezhilarasan D, Sokal E, Najimi M. Hepatic fibrosis: It is time to go with hepatic stellate cell-specific therapeutic targets. Hepatobiliary Pancreat Dis Int. 2018 Jun;17(3):192-197.Pubmed PMID: 29709350.

[13]. Goswami M, Verma A, Verma M. Benign migratory glossitis with fissured tongue. J Indian Soc Pedod Prev Dent. 2012 Apr 1;30(2):173-75.

[14]. Govindaraju L, Neelakantan P, Gutmann JL. Effect of root canal irrigating solutions on the compressive strength of tricalcium silicate cements. Clin Oral Investig. 2017 Mar;21(2):567-571.Pubmed PMID: 27469101

[15]. Gupta P, Ariga P, Deogade SC. Effect of Monopoly-coating Agent on the Surface Roughness of a Tissue Conditioner Subjected to Cleansing and Disinfection: A Contact Profilometric In vitro Study. Contemp Clin Dent. 2018 Jun;9(Suppl 1):S122-S126.Pubmed PMID: 29962776.

[16]. Harsha L, Brundha MP. Prevalence of dental developmental anomalies among men and women and its psychological effect in a given population. Res J Pharm Biol Chem Sci [Internet]. 2017; 9 (6): 869.

[17]. Hume WJ. Geographic stomatitis: a critical review. J Dent. 1975 Jan;3(1):2543.Pubmed PMID: 1091680.

[18]. Ishibashi M, Tojo G, Watanabe M, Tamabuchi T, Masu T, Aiba S. Geo- graphic tongue treated with topical tacrolimus. J. Dermatol. Case Rep. 2011 Dec 31;4(4):57.

[19]. Jainkittivong A, Langlais RP. Geographic tongue: clinical characteristics of 188 cases. J Contemp Dent Pract. 2005 Feb 15;6(1):123-35.Pubmed PMID: 15719084 .

[20]. Kovač-Kavčič M, Skalerič U. The prevalence of oral mucosal lesions in a population in Ljubljana, Slovenia. J. Oral Pathol. Med. 2000 Aug;29(7):331-5.

[21]. Kumar T, Puri G, Aravinda K, Arora N. Benign migratory glossitis: A rare presentation of a common disorder. J Indian Acad Oral Med Radiol. 2015 Jan 1;27(1):112.

[22]. Maheswari TNU, Venugopal A, Sureshbabu NM, Ramani P. Salivary micro RNA as a potential biomarker in oral potentially malignant disorders: A systematic review. Ci Ji Yi Xue Za Zhi. 2018 Apr-Jun;30(2):55-60.Pubmed PMID: 29875583.

[23]. Mathew AL, Pai KM, Sholapurkar AA, Vengal M. The prevalence of oral mucosal lesions in patients visiting a dental school in Southern India. Indian J Dent Res. 2008 Apr 1;19(2):99-103.

[24]. Mathew MG, Samuel SR, Soni AJ, Roopa KB. Evaluation of adhesion of Streptococcus mutans, plaque accumulation on zirconia and stainless steel crowns, and surrounding gingival inflammation in primary molars: randomized controlled trial. Clin Oral Investig. 2020 Sep;24(9):1-6.Pubmed PMID: 31955271.

[25]. Misra SR, Shankar YU, Rastogi V, Maragathavalli G. Metastatic hepatocellular carcinoma in the maxilla and mandible, an extremely rare presentation. Contemp Clin Dent. 2015 Mar;6(Suppl 1):S117-21.

[26]. Muthukrishnan A, Kumar LB. Actinic cheilosis: early intervention prevents malignant transformation [Internet]. BMJ Case Rep. 2017:bcr2016218654.

[27]. Muthukrishnan A, Bijai Kumar L, Ramalingam G. Medication-related osteonecrosis of the jaw: a dentist's nightmare. BMJ Case Rep. 2016 Apr 6;2016:bcr2016214626.Pubmed PMID: 27053542.

[28]. Muthukrishnan A, Warnakulasuriya S. Oral health consequences of smokeless tobacco use. Indian J Med Res. 2018 Jul;148(1):35-40.

[29]. Palati S, Ramani P, Shrelin HJ, Sukumaran G, Ramasubramanian A, Don KR, et al. Knowledge, Attitude and practice survey on the perspective of oral lesions and dental health in geriatric patients residing in old age homes. Indian J Dent Res. 2020 Jan-Feb;31(1):22-25.Pubmed PMID: 32246676.

[30]. Pandian KS, Krishnan S, Kumar SA. Angular photogrammetric analysis of the soft-tissue facial profile of Indian adults. Indian J Dent Res. 2018 Mar 1;29(2):137-43

[31]. Paramasivam A, Vijayashree Priyadharsini J, Raghunandhakumar S. N6adenosine methylation (m6A): a promising new molecular target in hypertension and cardiovascular diseases. Hypertens Res. 2020 Feb;43(2):153154.Pubmed PMID: 31578458.

[32]. Patil SR, Maragathavalli G, Araki K, Al-Zoubi IA, Sghaireen MG, Gudipaneni RK, et al. Three-rooted mandibular first molars in a Saudi Arabian population: A CBCT study. Pesqui Bras Odontopediatria Clin Integr. 2018 Aug 27;18(1):4133.

[33]. Pc J, Marimuthu T, Devadoss P, Kumar SM. Prevalence and measurement of anterior loop of the mandibular canal using CBCT: A cross sectional study. Clin Implant Dent Relat Res. 2018 Apr 6;20(4):531-4.

[34]. Prinz H. Wandering rash of the tongue (geographic tongue). Dent Cosmos. 1927;69:272-5

[35]. Vijayashree Priyadharsini J, Smiline Girija AS, Paramasivam A. In silico analysis of virulence genes in an emerging dental pathogen A. baumannii and related species. Arch Oral Biol. 2018 Oct;94:93-98.Pubmed PMID: 30015217.

[36]. Priyanka S, Kaarthikeyan G, Nadathur JD, Mohanraj A, Kavarthapu A. Detection of cytomegalovirus, Epstein-Barr virus, and Torque Teno virus in subgingival and atheromatous plaques of cardiac patients with chronic periodontitis. J Indian Soc Periodontol. 2017 Nov-Dec;21(6):456-460.Pubmed PMID: 29551863.

[37]. Ramadurai N, Gurunathan D, Samuel AV, Subramanian E, Rodrigues SJ. Effectiveness of $2 \%$ Articaine as an anesthetic agent in children: randomized controlled trial. Clin. Oral Investig. 2019 Sep;23(9):3543-50.

[38]. Ramamurthy JA, Mg V. Comparison of effect of Hiora mouthwash versus Chlorhexidine mouthwash in gingivitis patients: A clinical trial. Asian J Pharm Clin Res. 2018 Jul 7;11(7):84-8.

[39]. Ramesh A, Varghese S, Jayakumar ND, Malaiappan S. Comparative estimation of sulfiredoxin levels between chronic periodontitis and healthy patients - A case-control study. J Periodontol. 2018 Oct;89(10):1241-1248.Pubmed PMID: 30044495.

[40]. Redman RS. Prevalence of geographic tongue, fissured tongue, median rhomboid glossitis, and hairy tongue among 3,611 Minnesota schoolchildren. Oral Surg Oral Med Oral Pathol. 1970 Sep;30(3):390-5.Pubmed PMID: 5270895.

[41]. R H, Ramani P, Ramanathan A, R JM, S G, Ramasubramanian A, et al. CYP2 C9 polymorphism among patients with oral squamous cell carcinoma 
and its role in altering the metabolism of benzo[a]pyrene. Oral Surg Oral Med Oral Pathol Oral Radiol. 2020 Sep;130(3):306-312.Pubmed PMID: 32773350 .

[42]. Rohini S, Kumar VJ. Incidence of dental caries and pericoronitis associated with impacted mandibular third molar-A radiographic study. Res J Pharm Technol. 2017;10(4):1081-4.

[43]. Samuel SR. Can 5-year-olds sensibly self-report the impact of developmental enamel defects on their quality of life? Int J Paediatr Dent. 2021 Mar;31(2):285-286.Pubmed PMID: 32416620.

[44]. Samuel SR, Acharya S, Rao JC. School Interventions-based Prevention of Early-Childhood Caries among 3-5-year-old children from very low socioeconomic status: Two-year randomized trial. J Public Health Dent. 2020 Jan;80(1):51-60.Pubmed PMID: 31710096.

[45]. Sapiro SM, Shklar G. Stomatitis areata migrans. Oral Surg Oral Med Oral Pathol . 1973 Jul 1;36(1):28-33.

[46]. Sitharthan R, Sundarabalan CK, Devabalaji KR, Yuvaraj T, Mohamed Imran A. Automated power management strategy for wind power generation system using pitch angle controller. Meas. Control. 2019 Mar;52(3-4):169-82.

[47]. Sridharan G, Ramani P, Patankar S, Vijayaraghavan R. Evaluation of salivary metabolomics in oral leukoplakia and oral squamous cell carcinoma. J. Oral Pathol. Med. 2019 Apr;48(4):299-306.

[48]. Steele JC, Clark HJ, Hong CH, Jurge S, Muthukrishnan A, Kerr AR, et al. World Workshop on Oral Medicine VI: an international validation study of clinical competencies for advanced training in oral medicine. Oral Surg
Oral Med Oral Pathol Oral Radiol. 2015 Aug;120(2):143-51.e7.Pubmed PMID: 25861956

[49]. Subashri A, Maheshwari TN. Knowledge and attitude of oral hygiene practice among dental students. Res J Pharm Technol. 2016;9(11):1840-2.

[50]. Subha M, Arvind M. Role of magnetic resonance imaging in evaluation of trigeminal neuralgia with its anatomical correlation. Biomed. pharmacol. J. 2019 Mar 25;12(1):289-96.

[51]. Swetha S, Kumar JV. Stomatitis-An Overview. J. Pharm. Sci. Res. 2019 Jul 1;11(7):2656-8.

[52]. Umamaheswari, T. N. Salivary biomarkers in oral leukoplakia-a review. Int. J. Pharma Bio Sci.2014; 6(5):3014-3018.

[53]. Venugopal A, Uma Maheswari TN. Expression of matrix metalloproteinase-9 in oral potentially malignant disorders: A systematic review. J Oral Maxillofac Pathol. 2016 Sep-Dec;20(3):474-479.Pubmed PMID: 27721614.

[54]. Vijayashree Priyadharsini J. In silico validation of the non-antibiotic drugs acetaminophen and ibuprofen as antibacterial agents against red complex pathogens. J Periodontol. 2019 Dec;90(12):1441-1448.Pubmed PMID: 31257588.

[55]. Vikram NR, Prabhakar R, Kumar SA, Karthikeyan MK, Saravanan R. Ball Headed Mini Implant. J Clin Diagn Res. 2017 Jan;11(1):ZL02-ZL03.

[56]. Zingale JA. Migratory stomatitis: a case report. J. Periodontol. 1977 May 1;48(5):298-302. 